\title{
4 Maps Explaining the Growing Tensions in Central Asia
}

Monday, 24 April 2017 07:35 (EST)

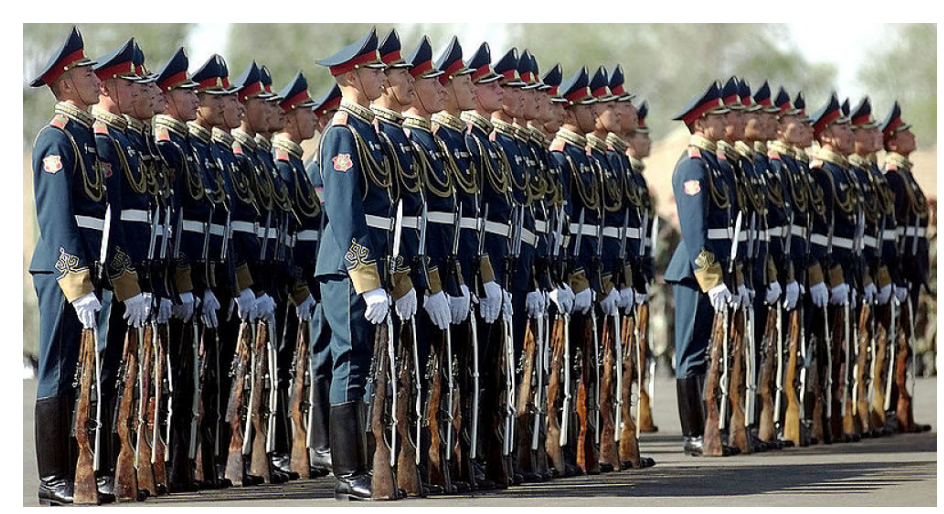

Central Asia is crumbling. The speed and extent of this leans in part on political and economic shifts in Russia, China, Afghanistan, and more. Geography is the main reason outside forces are shaping the growth of Central Asia.

Always trapped between major powers such as Russia and China, Central Asia is at risk of war.

(Download my FREE e-book, The World Explained in Maps, to get more insight into the forces shaping our physical and financial worlds.)

\section{Central Asian Geography}

The region goes from the Caspian Sea in the west to the Tien Shan Mountains in the south and the Altay Mountains in the east. 
The ranges split the region from Afghanistan in the south and China in the east. Kazakhstan, Uzbekistan, and Turkmenistan are mostly flat. Tajikistan and Kyrgyzstan are hilly.

In the north lies the vast Kazakh Steppe. Kazakhstan shares a flat, 3,000mile border with Russia. And like we wrote about in "Russia's Strategy,-, a border the country can't defend.

Yet even Central Asian countries distant from Russia and cut off from China by mountains are weak. Since the late 6oos, native Turkic forces, powers that held Persia (like Arabs and Turks), and the Chinese have all at some point run parts of the region.

Years of war and foreign rule led to the growth of weak states with deep inner soft spots in Central Asia. The region's modern borders are due to Soviet planners drawing them in the 1920 s and 1930 .

So, they are not innate. They do not quite show ethnic or national divides. 
For example, about $23 \%$ of Kazakhstan are ethnic Russians. Ethnic Uzbeks make up about 14\% of Kyrgyzstan and over 13\% of Tajikistan. Central Asia is a region of great ethnic and regional stress. They risk the unity of modern states.

\section{ETHNIC DISTRIBUTION IN CENTRAL ASIA AT INDEPENDENCE}

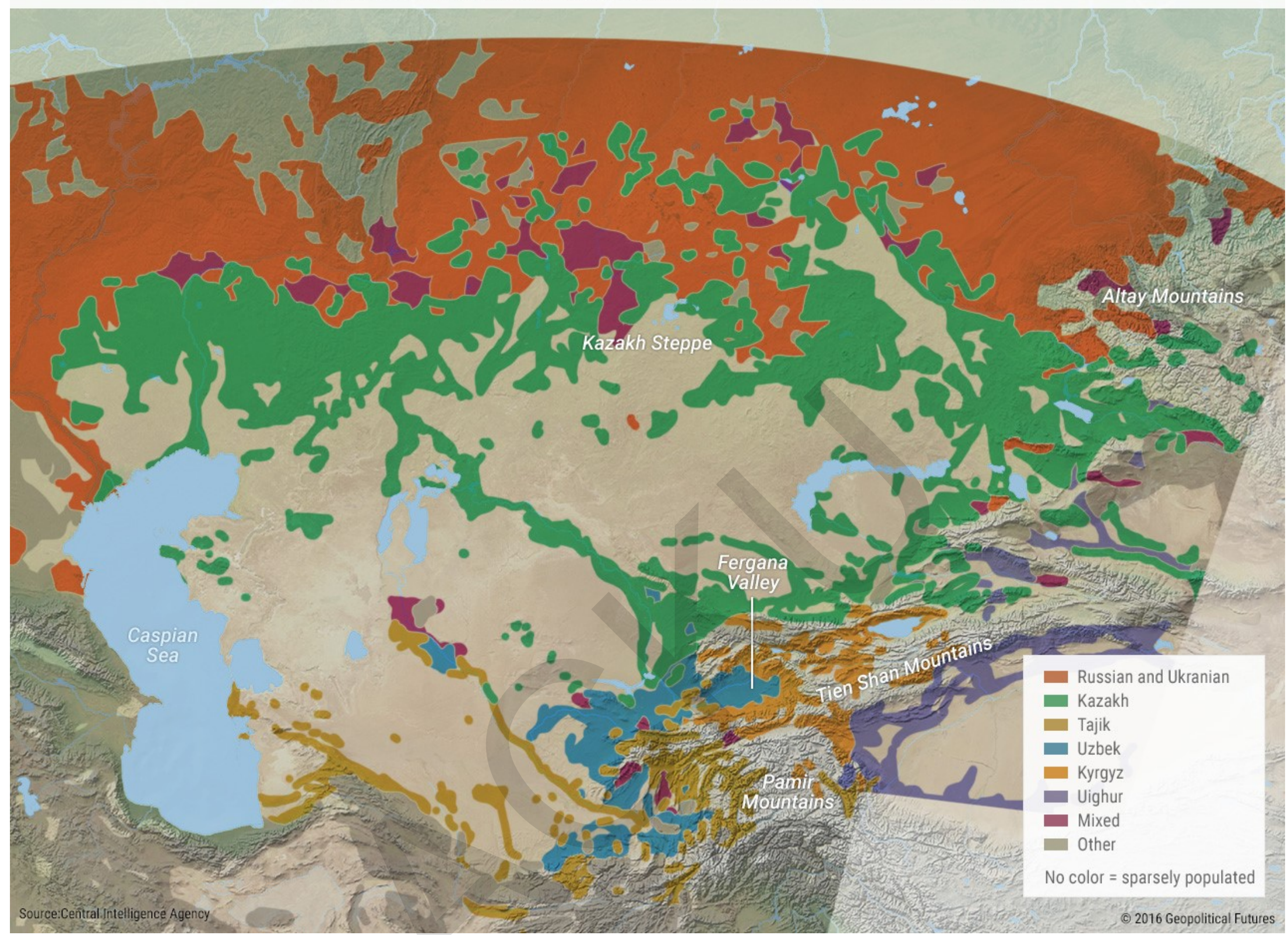

They risk the unity of modern states.

\section{Scare Resources Lead to Wars}

Geography and Soviet infrastructure planning lend to ongoing stress with the five Central Asian states. The main stress is strong fighting over scarce resources like water. The region needs two rivers, the Syr Darya and Amu Darya.

Under Soviet rule, the upstream countries (Tajikistan and Kyrgyzstan) gave water to the rest of the region through a centrally run plan. This managed the use of a reservoir and water distribution levels in the region 
based on Soviet economic goals.

Other countries, in turn, gave energy to resource-poor Tajikistan and Kyrgyzstan. After the fall of the USSR, fears grew-especially in Uzbekistan -over upstream countries using water for power generation.

\section{PIPELINES IN CENTRAL ASIA}

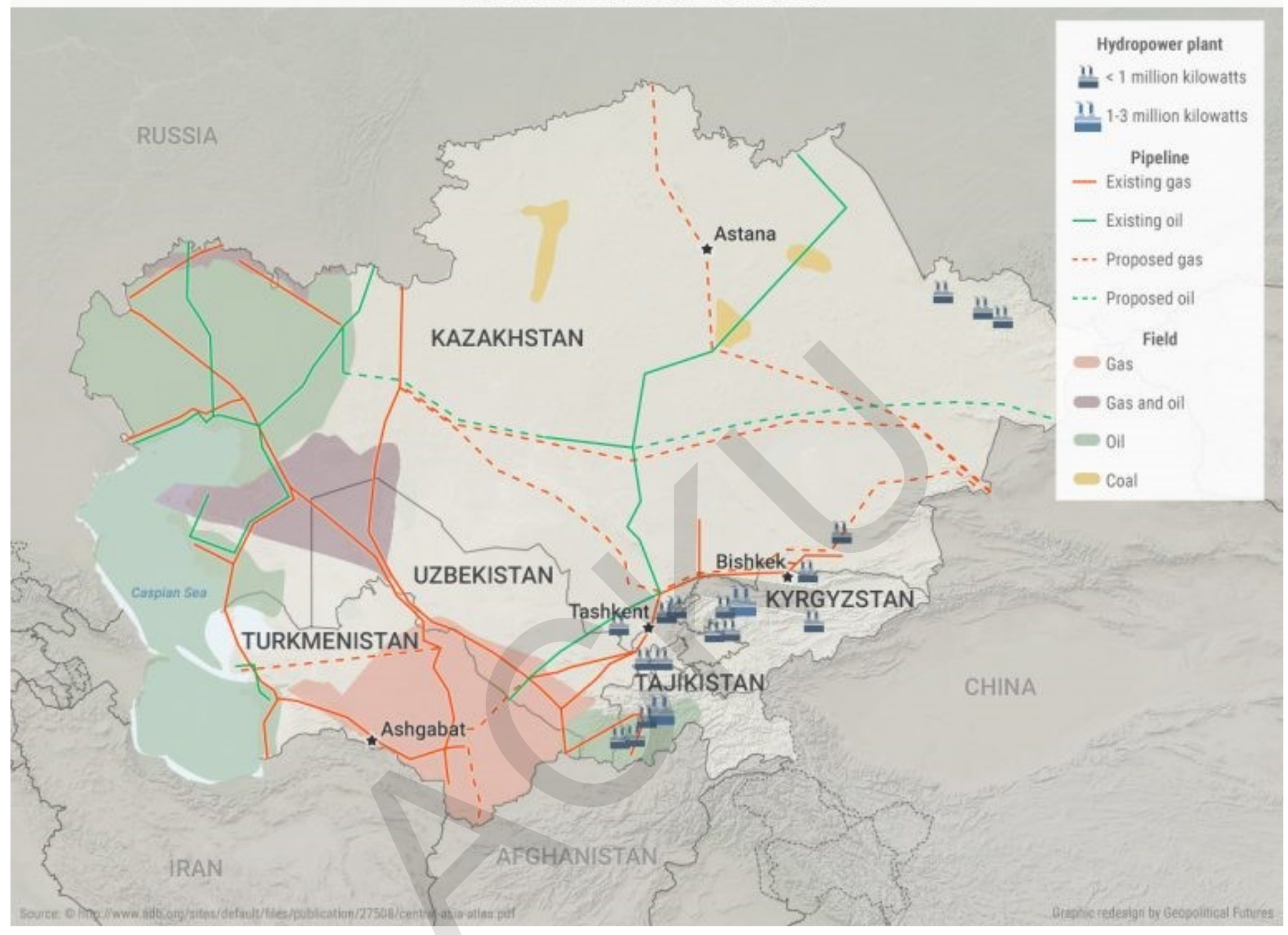

Scarce resources, population growth, and the use of energy and water to barter can heighten ethnic and border tensions. Especially in the lush and populous Fergana Valley. It is spread among Uzbekistan, Tajikistan, and Kyrgyzstan. 


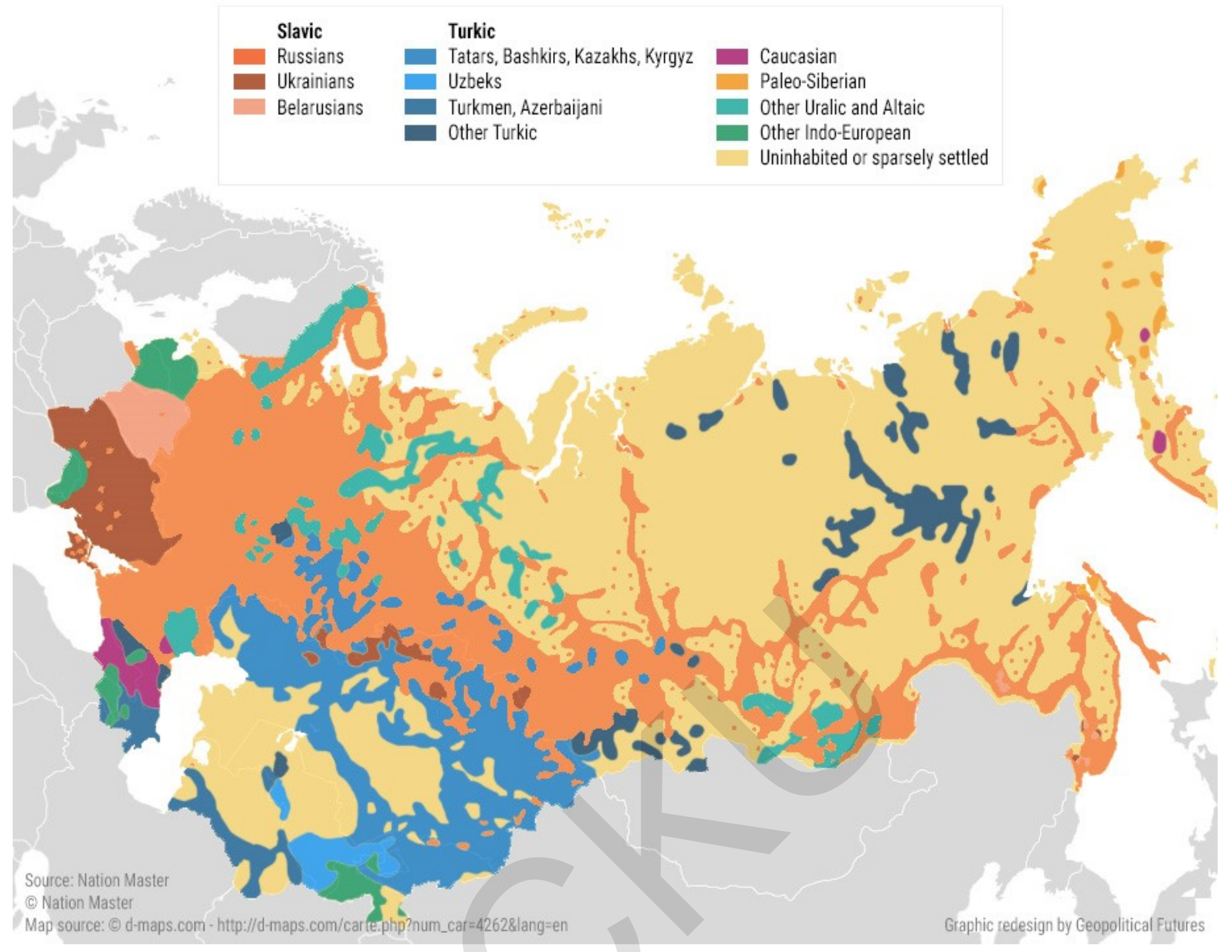

\section{Afghanistan Actors Threaten Central Asia}

The region's nearness to Afghanistan adds chaos. The US drawdown, plus an incoherent state, has let armed non-state actors to again rule Afghanistan. This then threatens Central Asia.

Afghanistan borders three Central Asian states: Turkmenistan, Uzbekistan, and Tajikistan. The country is now trying to return to its factional roots. With the US taking out most of its troops, the government in Kabul is up against a fast-growing Taliban insurgency.

In fact, the government is just one faction among many. The region's governments fear militants and violence spilling over. Also, Central Asian militants crossing into Afghanistan to meet with groups from the Taliban to the Islamic State working in the country-which we've written about at length. These militants could get training and arms that could be put to use 
in Central Asia. Central Asian militants are now fighting with IS and others in Syria and Iraq. They risk safety in their home states.

Geography is at the root of Central Asia's battles. It is fraught with tensions over ethnicity, Soviet-drawn borders, and high competition for resources. Plus, this complex and divided area is open to outside forces. Crises in nearby countries cause chaos in the region.

\section{Grab George Friedman's Exchsive eBook, The World Explained in Maps}

The World Explained in Maps reveals the panorama of geopolitical landscapes influencing today's governments and global financial systems. Don't miss this chance to prepare for the year ahead with the straight facts about every major country's and region's current geopolitical climate. You won't find political rhetoric or media hype here.

The World Explained in Maps is an essential guide for every investor as 2017 takes shape. Get your copy now-free!

DISCLOSURE: The views and opinions expressed in this article are those of the authors, and do not represent the views of equities.com. Readers should not consider statements made by the author as formal recommendations and should consult their financial advisor before making any investment decisions. To read our full disclosure, please go to: http://www.equities.com/disclaimer 